\title{
True Lateral Eye Numbers for Extant Buthids: A New Discovery on an Old Character
}

\author{
Xiaofeng Yang ${ }^{1 *}$, Yusoff Norma-Rashid ${ }^{2,3}$, Wilson R. Lourenço ${ }^{4}$, Mingsheng Zhu ${ }^{1 \dagger}$ \\ 1 College of Life Science, Hebei University, Baoding, Hebei Province, People's Republic of China, 2 Institute of Biological Sciences, Faculty of Science, University of Malaya, \\ Kuala Lumpur, Malaysia, 3 Department of Organismic and Evolutionary Biology, Harvard University, Cambridge, Massachusetts, United States of America, 4 Muséum \\ National d'Histoire Naturelle, Département Systématique et Evolution, Paris, France
}

\begin{abstract}
This study reports the results of a re-analysis of the number of lateral eyes in extant buthids. Specimens studied were confined mostly to those from China and the adjacent areas. 353 specimens belonging to 20 species (subspecies) and 8 genera were rechecked and found to have 5 pairs of lateral eyes contrary to earlier published works which reported the presence of 3 pairs of lateral eyes only. Combined with reported examples collected through reference investigation including 63 species from 16 genera, our study here shows a total of 79 species from 21 genera of scorpions spanning Asia and Africa had 5 pairs of lateral eyes. Reasons for not observing the presence of the extra lateral eyes are discussed and new protocols for examining specimens including using UV light are proposed to aid lateral eye recognition. Besides, a majority of genera in Buthidae are suggested to be in "Five-eye" model and a re-examination of all previously published taxonomic studies of buthid species is highly recommended.
\end{abstract}

Citation: Yang X, Norma-Rashid Y, Lourenço WR, Zhu M (2013) True Lateral Eye Numbers for Extant Buthids: A New Discovery on an Old Character. PLoS ONE 8(1): e55125. doi:10.1371/journal.pone.0055125

Editor: Eric James Warrant, Lund University, Sweden

Received October 23, 2012; Accepted December 14, 2012; Published January 30, 2013

Copyright: (c) 2013 Yang et al. This is an open-access article distributed under the terms of the Creative Commons Attribution License, which permits unrestricted use, distribution, and reproduction in any medium, provided the original author and source are credited.

Funding: The authors have no support or funding to report.

Competing Interests: The authors have declared that no competing interests exist.

*E-mail: YangxiaofengChina@yahoo.com

$†$ Deceased.

\section{Introduction}

Eye features are widely known to be important characters in the study of taxonomy in most arthropod groups. Scorpions have two types of eyes, namely, the median and lateral eyes. Most scorpions have two median eyes, only several species lacks. The number of lateral eyes varies among different major groups of extant scorpions. The evolution trend of this feature is unknown.

Koch [1] was the first to think highly of the number of lateral eyes in scorpion taxonomy. He attempted to classify the genera into families based on the number of lateral eyes: Scorpionidea (two pairs); Buthidea (three pairs); Centruridea (four pairs); and Androctonidea (five pairs). Lankester [2] pointed out that the number of lateral eyes was unstable and Koch's classification was unreliable. Thus subsequent taxonomists did not use this character at higher taxonomic levels in extant scorpions. Later, Stockwell [3] further supported Lankester's point and reported that Koch's classification groups were inaccurate resulting in incorrect assignation of many of the genera. Kjellesvig-Waering [4] restudied fossil scorpions of the world and placed a high value on the disposition of the lateral eyes concluding that the reduction in lateral eye units was an evolutionary trend which led to the available recent taxa. Stockwell [3] affirmed Kjellesvig-Waering's opinion in fossil scorpions in his unpublished $\mathrm{PhD}$ thesis, but he did not emphasize on the importance of lateral eyes in the extant groups. Soleglad and Fet [5] re-analyzed the higher taxonomic system with 105 characters selected from all extant families which included the lateral eyes counts. However they denoted the numbers from Buthidae and Pseudochactidae as "uninformative data".

Huge subsequent taxonomic changes have taken place since the era of Koch. With a number of 971 species and 89 genera [6], family Buthidae is the largest family in Scorpionida, representing almost half of the species and genera of the known scorpions. All of the above suggest great potential significance and necessity on further research for family Buthidae on this subject. Hence the study on lateral eye counts in buthids is proposed in this current work.

\section{Materials and Methods}

\section{Material Examined}

A total of 353 specimens belonging to 20 species (subspecies) and 8 genera were reexamined including 18 species (subspecies) involved in 7 genera from China and adjacent areas of Asia, 2 species involved in 1 genus from Africa.

Mesobuthus (8 species and subspecies): Mesobuthus martensii martensii (Karsch, 1879), 550’, 94ㅇ, 30 juv, China: Liaoning, Hebei, Ningxia, Qinghai; Mesobuthus eupeus mongolicus (Birula, 1911), 40", 8Q, China: Inner Mongolia, Gansu, Ningxia, Xinjiang; Mesobuthus eupeus thersites (G. L. Koch, 1839), 100*, 14o,, 2 juv, China, Uzbekistan, Kazakhstan; Mesobuthus caucasicus intermedius (Birula, 1897), 200'10Q, Kazakhstan, Uzbekistan; Mesobuthus caucasicus przewalskii (Birula, 1897), 10’,1Q, China; Mesobuthus karshius Sun \& Sun, 2011, holotype + , paratype 10̛,1@, China; Mesobuthus longichelus Sun \& Zhu, 2010, holotype \&, 2 juv, China; Mesobuthus 
bolensis Sun, Zhu \& Lourenço,2010, holotype O’, paratype 10", China.

Hottentotta (2 species): Hottentotta songi (Lourenço, Qi \& Zhu, 2005), paratype 10’, 1o, 1 juv, China; Hottentotta tamulus (Fabricius, 1798), 1 , 1 juv, India.

Isometrus (4 species): Isometrus (Isometrus) maculatus (DeGeer, 1778), 2 juv, China; Isometrus (Reddyanus) hainanensis Lourenço, Qi \& Zhu, 2005, Paratype 10,10", China; Isometrus (Reddyanus) tibetanus Lourenço \& Zhu, 2008, holotype O*. China; Isometrus (Reddyanus) assamensis Oates, 1888. 2ᄋ,10", India.

Lychas (1 species): Lychas mucronatus (Fabricius, 1798), 290", 44ㅇ, 4 juv, Vietnam, China: Yunnan, Hainan.

Razianus (1 species): Razianus xinjianganus Lourenço, Sun \& Zhu, 2010, Holotype o, China.

Sassanidotus (1 species): Sassanidotus gracilis (Birula, 1900), 1o, Iran. Kraepelinia(1 species): Kraepelinia palpator, 10, Iran.

Buthus (2 species): Buthus occidentalis Lourenço, Sun \& Zhu, 2009, 1Q, 1 juv, Mauritania; Buthus draa Lourenço \& Slimani, 2004, topotype 1\%, Morocco.

\section{Examination, Photography, Measuration and Illustration}

Specimens were examined and photographed using the white and violet lights (wavelength range: $390-420 \mathrm{~nm}$ ). Photos of lateral eyes were captured using the equipment set-up model, Nikon SMZ1500 Stereomicroscope, Nikon CF Plan 10X Objective and Canon 60D SLR.

A standard histological technique was used to prepare longitudinal and transverse ultrathin sections of the lateral eyes. The technique involved preparation of specimen paraffin blocks which were sectioned using ultramicrotome with glass knives to obtain 60-90 nm sections. These sections were stained with hematoxylin, later examined, measured and photographed with Leica DM 2000 Microsystems.

Drawings were made by using Photoshop 8.01 and Wacom Intuos 3 pen tablet.

\section{Definition of Terms}

There was no species found to have more than five pairs of lateral eyes and the relative position of each lateral eye was comparatively fixed within species (for details, see below). Therefore, five pairs of lateral eyes were suggested to be a standard model here and the ordinal number No. 1-5 refer to each pair of the lateral eyes for convenience of recording and describing (after Fleissner [7,8]). The model described here is illustrated in Figure 1(A, B).

The location of the lateral eye No. 4 showed variation to a certain degree across species and sometimes, even within the same species. P1-P3 were assigned to show the three possible locations of the No. 4 lateral eye. Locations of No. 4 and No. 5 lateral eyes could also be determined by the angle formed by two lines, one through the center of the No. 4 (or No. 5) and No. 3, the other line through the center of the No. 1 and No. 3. Angle names $\theta$ and $\phi$ were assigned to use for describing No. 4 and No. 5 lateral eyes respectively. (Figure 1. C \& D).

\section{Results}

In the widespread Chinese subspecies, M. martensii martensii, we found 2 extra pairs of lateral eyes here labeled as No. 4 and No. 5 when examined under the UV light (Figure 2. A). In contrast, these 2 lateral eyes were difficult to recognize when specimens were examined under normal white light (Figure 2. B). We also found different depictions on this number in previous publications, i.e. 5 in Kishida [9], 3 in Qi, et al. [10] and Sun \& Sun [11].
To confirm the existence of these extra pairs of lateral eyes and to discount confusion with tubercle structures on the carapace, we performed a dissection on the carapace to prepare histological sections for examination, which resulted in affirmation of eyes No. 4 and No. 5 (Figure 2. C, D). The measurements of the two micro-eyes were $0.12 \mathrm{~mm}$ in diameter in contrast to No. 1 to No. 3 eyes which were all $0.3 \mathrm{~mm}$ in diameter. Additionally, 550", 940 and 30 juv collected from 4 different locations were reexamined to avoid partial conclusion due to variation among local populations and individuals. The statistical result can be seen in Table 1 which shows good consistency with 5 lateral eyes.

Besides, a total of 353 specimens belonging to 20 species and subspecies in 8 genera were re-examined successively to see how many buthids exhibit this number and whether they were reported properly within our collection. The statistical results were tabulated in Table 1. Selected representatives and exceptional specimens were photographed (Figure 2, Figure 3 and Figure 4). All except 5 species and subspecies previously reported with 3 or 4 pairs of lateral eyes, on re-examination had 5 pairs. The two pairs of minute lateral eyes, No. 4 and No. 5 have been overlooked.

Furthermore, we conducted reference investigations to see how many previously reported buthids with 5 pairs of lateral eyes and what and where they are. Table 2 is a summary of related publications we found, involving 63 species from 16 genera. Together with those in Table 1, this would add up to 79 species and 21 genera. Though this would account for only a small proportion in the family Buthidae and not exhaustive, these examples come from many different locations scattering Asia and Africa where contains all the buthid genera in the Old World what make it can not be easily ignored.

During the reexamination, we found variations in the number and location of lateral eyes. The counts of numbers of eyes ranged between 4 to 6 (Figure 3, Figure 4 and Table 1). The eye No. 4 has three possible locations, P1, P2 or P3 (Figure 1. B). Most are at P1 or $\mathrm{P} 2$ and very few at $\mathrm{P} 3$ (Figure 3. Q, R, S, T) among different species.

As another result of the above work, we summarized possible reasons leading to overlooking on lateral eyes No. 4 and No. 5 in previous studies here.

1. Eyes No. 4 \& 5 were smaller in size in contrast to No. 1-3 lateral eyes (only about one third to half the size of No. 1-3 eyes, Figure 2).

2. Under the stereomicroscope, the eyes No. 4 \& 5 were much resembling tubercles on the carapace and almost indistinguishable in size and shape in most cases, (Figure2. B). This also could be due to the semi-transparent appearance of either the tubercles or micro-lateral eyes when under the normal white or yellow light (Figure2. B).

3. The sizes and locations of the lateral eyes were variable among different species and also among different specimens in one species. In some cases, the No. 4 was bigger than No. 5, in other cases, it was the opposite, and in most cases they were almost equivalent in size. Recognition and location was particularly difficult when the two eyes were both smaller than the average sizes.

4. Exceptions as shown in Figure 4 with insufficient sampling could be another reason contributing to this issue.

Also, we acquired a number of protocols proved to be useful in the process of reexamining the specimens, in increasing the accuracy in determining, recognizing and locating No. 4 \& No. 5 lateral eyes. 

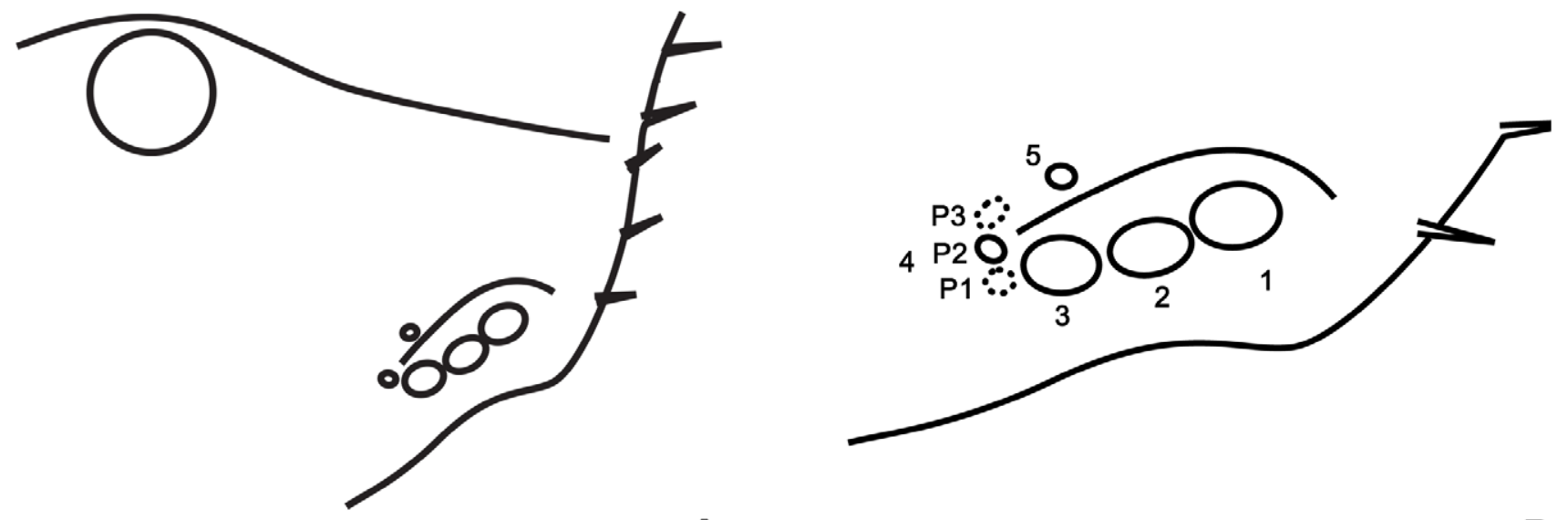

A

B
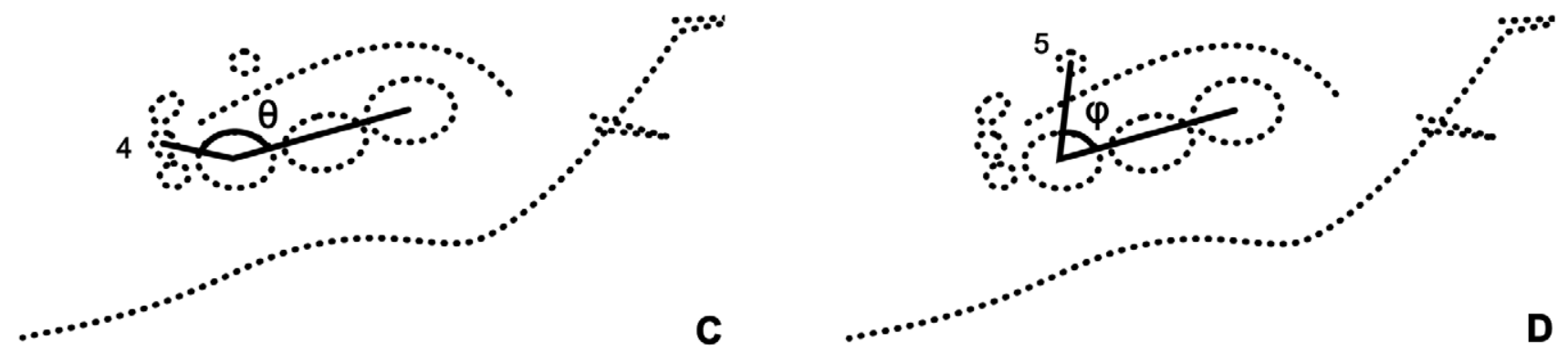

Figure 1. Models of lateral eye area. (A) The position of lateral eye area on Carapace; (B) Supposed model of 5 lateral eyes, P1, P2, P3 are 3 possible locations of the No. 4 lateral eyes; (C) Angle $\theta$, indicating the location of No. 4 lateral eye; (D) Angle $\phi$, indicating the location of No. 5 lateral eye.

doi:10.1371/journal.pone.0055125.g001

1. The position of No. 4 could be variable. On the carapace (dorsal view), three types were apparent: (1) Posterior-lateral (Figure 1. B P1), similar to the positions of No. 1-3, (2) Posterior, at the posterior end of lateral eye carina composed with tubercles (if present) (Figure 1. B P2), (3) Dorsal-posterior, locating at the inner side of the line composed with lateral eye tubercles (if present) (Figure 1. B P3). Although the variation may be slight but the No. 4 could easily be confused with the many tubercles within ocular area of lateral eyes.

2. Using the Figure $1(B, C \& D)$ with reference of angles $\theta, \phi$ is a helpful guide in determining the locations of the two lateral eyes.

3. Changing different directions of view during the examination of specimens will help in locating the No. 4 and No. 5 lateral eyes. Placing specimens well submerged in alcohol in beakers rather than in shallow alcohol of petri dishes would help in the examination as well as in the photography.

4. The lateral eyes have no fluorescence under the UV light [49], because the laterals eyes are composed with lens outside, while the tubercles are actually thickened cuticle and thus exhibit stronger fluorescence. Such characteristics can be exploited to distinguish lateral eyes from tubercles, no matter how minute these lateral eyes might be (Figure 3. H, J, L, N, V).

5. The cuticle of the scorpion is almost transparent. Each lateral eye has light sensitive dark tissue under the lens. Therefore, most researchers recorded dark "splash" around the lateral eyes, while they were not real splashes. Even if there were pigments near the lateral eyes, the darkening would be different. When specimens were anatomized, the pigments was found to be located in a thin pigment layer just beneath the cuticle, while the light sensitive dark tissues were much thicker and separated from the cuticle. The No. 5 is usually located in a separated dark "splash" or on a protruding "splash" connecting with the "splashes" around the No. 1-4.

6. Five pairs of lateral eyes are much easily seen in specimens of early instars. In a check of 27 specimens of second instar $M$. martensii martensii, no tubercle was found as big as the No. 4 or No. 5. So, this provides us an efficient and effective way to confirm this character.

7. In some specimens with light sensitive eye tissues separated from the lens for some reason, we could find some tissue scraps forming complete or half circle around the inner edges of the lens, while the pigment did not present like this around the inner side of tubercles. In such specimens this would assist in locating the eyes No. 4 and No. 5. And also, according to this phenomenon, these two lateral eyes could be well recognized by splitting the cuticle and finding the lens adhered with dark tissue from the inner side.

8. Taking photos under UV light would produce clear and sharp images of the lateral eyes which would help in situations when the lateral eyes are too small or the fluorescence is too faint to confirm by using any of the methods outlined above.

9. Lateral eyes No. 4 and No. 5 have different features providing us a method to distinguish them from each other. (1) The angle 

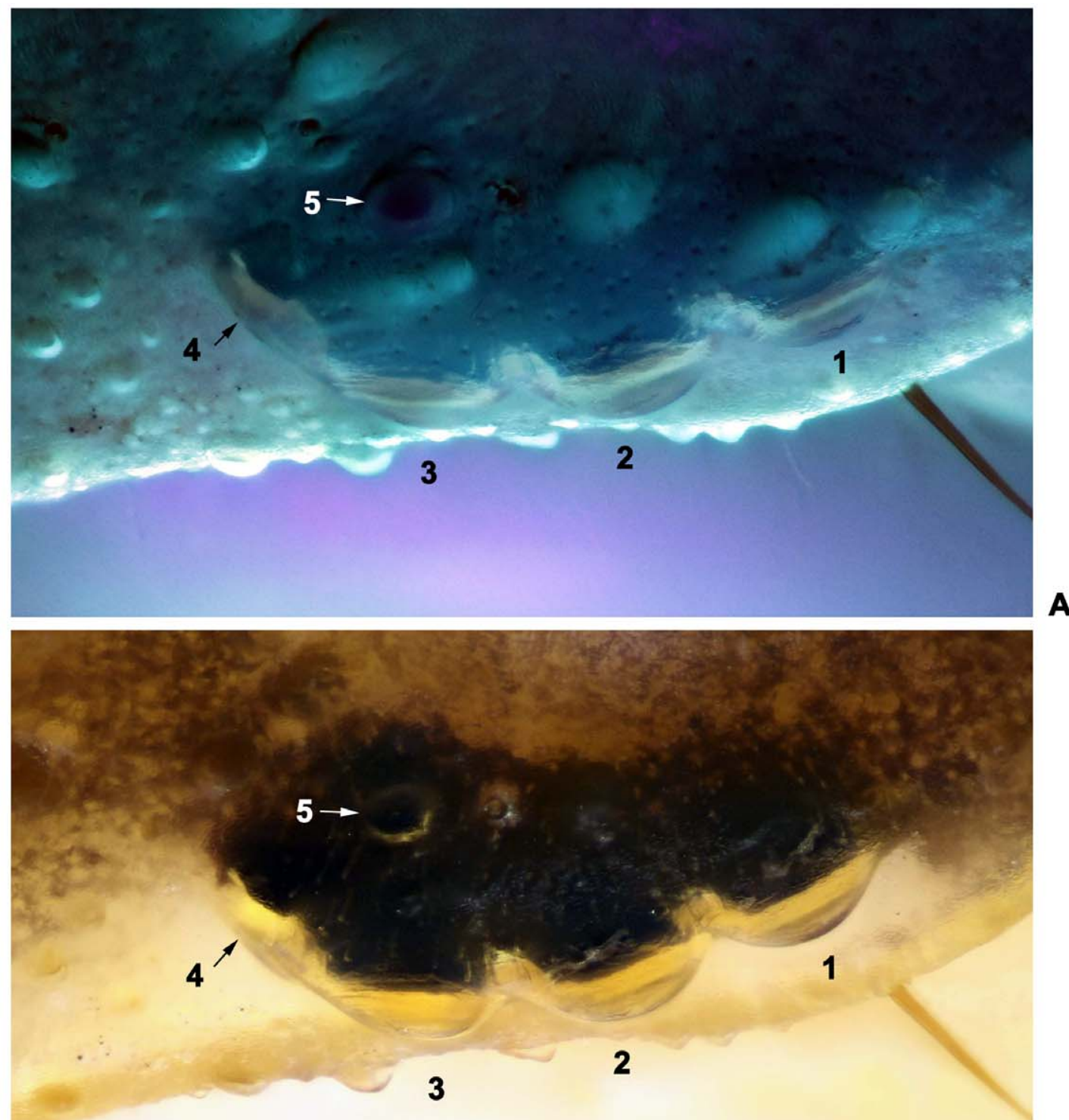

B
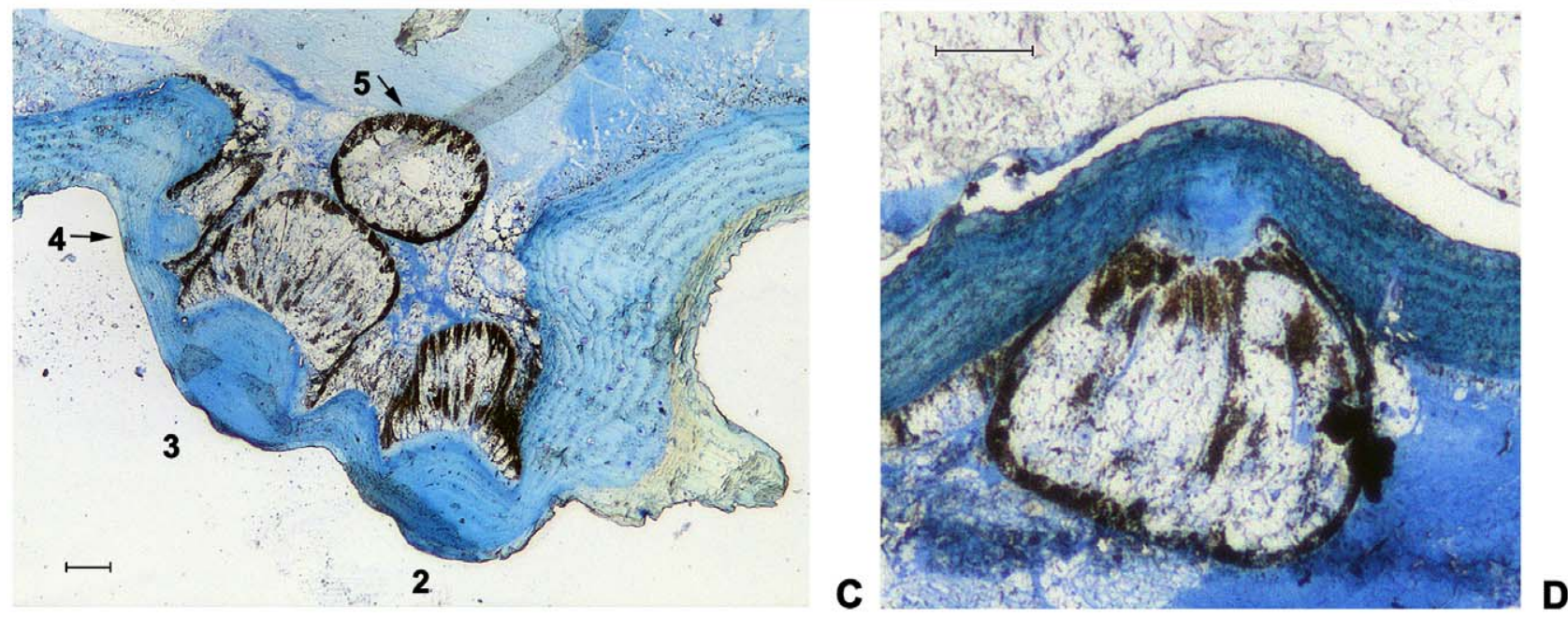
Figure 2. Lateral eyes of $\boldsymbol{M}$. martensii martensii. (A) Under UV light; (B) Under white light; (C) Longitudinal section of No. 2-4 lateral eyes with transverse section of No. 5 lateral eye. $0.1 \mathrm{~mm}$; (D) Longitudinal section of No. 5 lateral eye. $0.1 \mathrm{~mm}$.

doi:10.1371/journal.pone.0055125.g002

$\theta$ of No. 4 is always $>90$ degrees and $<180$ degrees, while the angle $\phi$ of No. $5<90$ degrees (Figure 1. C, D; Figure 2. A, B; Figure 3). (2) Lateral eye No. 4 always looks towards posteriorly, posterior-laterally or dorsal-posteriorly, while the No. 5 always looks towards dorsally (Figure 1. B; Figure 2. A, B, C; Figure 3).

\section{Discussion}

Difficulties in recognizing the No. 4 and No. 5 lateral eyes were first reported by Lankester \& Bourne [29] who stated: "The smaller lenses are equally entitled to count as eyes with the larger. It is, however, difficult without great care and minute examination to distinguish mere tubercles of the chitinous integument from eye- lenses." But their studies were concerned cells and tissues, and missed the attention of taxonomists. Kovařík [50] found four lateral eyes for Butheolus species, and pointed out that "the fourth eye" "may possibly be overlooked". In our study, we found species M. martensii $[9,10,11,15]$, M. caucasicus $[11,15,16,17,51]$ and $M$. eupeus with their subspecies $[11,12,13,14,15,51]$ were studied numerous of times. Though there was no lack of good descriptions with drawings or high-tech photography among these studies, e.g. Qi, et al. [10], Sun \& Zhu [16], Mirshamsi, et al. [14], Sun \& Sun [11], these "extra" lateral eyes were also not mentioned. Even the scanning electron microscopy were used in morphological studies, the same case still occurs, for example, Figure 2 of Lourenço \& Leguin [26] illustrated a "Five-eye" model, but unfortunately, the No. 4 and 5 lateral eyes were not recognized. Therefore, the

Table 1. Status Update and Statistics of Rechecked Specimens.

\begin{tabular}{|c|c|c|c|c|c|c|}
\hline $\begin{array}{l}\text { Species/ } \\
\text { Subspecies }\end{array}$ & $\begin{array}{l}\text { Reported } \\
\text { Number }\end{array}$ & $\begin{array}{l}\text { Rechecked } \\
\text { Result }\end{array}$ & $\begin{array}{l}\text { Rechecked } \\
\text { Specimens }\end{array}$ & Location(s) & Exceptions & $\begin{array}{l}\text { References } \\
\text { Studied }\end{array}$ \\
\hline M. martensii martensii & $3 \& 5$ & 5 & $\begin{array}{l}550^{\prime}, 940,30 \\
\text { juv }\end{array}$ & $\begin{array}{l}\text { China (Liaoning, Hebei, } \\
\text { Ningxia, Qinghai) }\end{array}$ & $\begin{array}{l}5 \text { specimens lack No. } 4 \text { on one } \\
\text { side; } 1 \text { specimen lacks } \\
\text { No. } 2 \text { on one side }\end{array}$ & {$[9,10,11]$} \\
\hline M. eupeus mongolcus & 3 & 5 & $40^{\prime}, 80$ & $\begin{array}{l}\text { China (Inner Mongolia, Gansu, } \\
\text { Ningxia, Xinjiang) }\end{array}$ & $\begin{array}{l}1 \text { specimen has } 6 \text { lateral } \\
\text { eyes on both sides }\end{array}$ & {$[11,12,13]$} \\
\hline M. eupeus thersites & 3 & 5 & $\begin{array}{l}100 ;, 14 Q, 2 \\
\text { juv }\end{array}$ & $\begin{array}{l}\text { China, Uzbekistan, } \\
\text { Kazakhstan }\end{array}$ & & {$[12,13,14,15]$} \\
\hline $\begin{array}{l}\text { M. caucasicus } \\
\text { przewalskii }\end{array}$ & 3 & 5 & 10",10 & China & & {$[11,15,16,17]$} \\
\hline $\begin{array}{l}\text { M. caucasicus } \\
\text { intermedius }\end{array}$ & 3 & 5 & 200",10@ & $\begin{array}{l}\text { Kazakhstan, } \\
\text { Uzbekistan }\end{array}$ & $\begin{array}{l}1 \text { specimen lacks No. } 2 \text {; } \\
1 \text { specimen has } 6 \text { lateral } \\
\text { eyes on one side }\end{array}$ & {$[11,15,16,17]$} \\
\hline M. bolensis & 3 & 5 & $10 *, 10$ & China & & {$[18]$} \\
\hline M. longichelus & 3 & 5 & $\begin{array}{l}1 \text { i, } 2 \\
\text { juv }\end{array}$ & China & & {$[16]$} \\
\hline M. karshius & 3 & 5 & $10 *, 2 @$ & China & & {$[11,18]$} \\
\hline H. songi & 3 & 5 & $\begin{array}{l}10,10,1 \\
\text { juv }\end{array}$ & China & & {$[18,19]$} \\
\hline H. tamulus & 5 & 5 & $\begin{array}{l}19,1 \\
\text { juv }\end{array}$ & India & & {$[20]$} \\
\hline $\begin{array}{l}\text { I. (Isometrus) } \\
\text { maculatus }\end{array}$ & 5 & 5 & 2 juv & China & & {$[20]$} \\
\hline $\begin{array}{l}\text { I. (Reddyanus) } \\
\text { hainanensis }\end{array}$ & 3 & 5 & $10 ;, 10$ & China & & {$[21]$} \\
\hline $\begin{array}{l}\text { I. (Reddyanus) } \\
\text { tibetanus }\end{array}$ & 3 & 5 & $10^{\prime}$ & China & & {$[22]$} \\
\hline $\begin{array}{l}\text { I. (Reddyanus) } \\
\text { assamensis }\end{array}$ & $3 \& 5$ & 5 & $10 *, 2 Q$ & India & & {$[20,22]$} \\
\hline L. mucronatus & 5 & 5 & $\begin{array}{l}290^{\prime}, 44 \%, 4 \\
\text { juv }\end{array}$ & $\begin{array}{l}\text { Vietnam, China } \\
\text { (Yunnan, Hainan) }\end{array}$ & $\begin{array}{l}1 \text { specimen lacks } \\
\text { No. } 5 \text { on both sides }\end{array}$ & {$[20,23]$} \\
\hline R. xinjianganus & 3 & 5 & 10 & China & & {$[24]$} \\
\hline S. gracilis & 3 & 5 & 10 & Iran & & {$[24]$} \\
\hline B. draa & 3 & 5 & 10 & Morocco & & {$[25]$} \\
\hline B. occidentalis & 4 & 5 & $\begin{array}{l}10,1 \\
\text { juv }\end{array}$ & Mauritania & & {$[25]$} \\
\hline K. palpator & 3 & 5 & 10 & Iran & & {$[26]$} \\
\hline
\end{tabular}




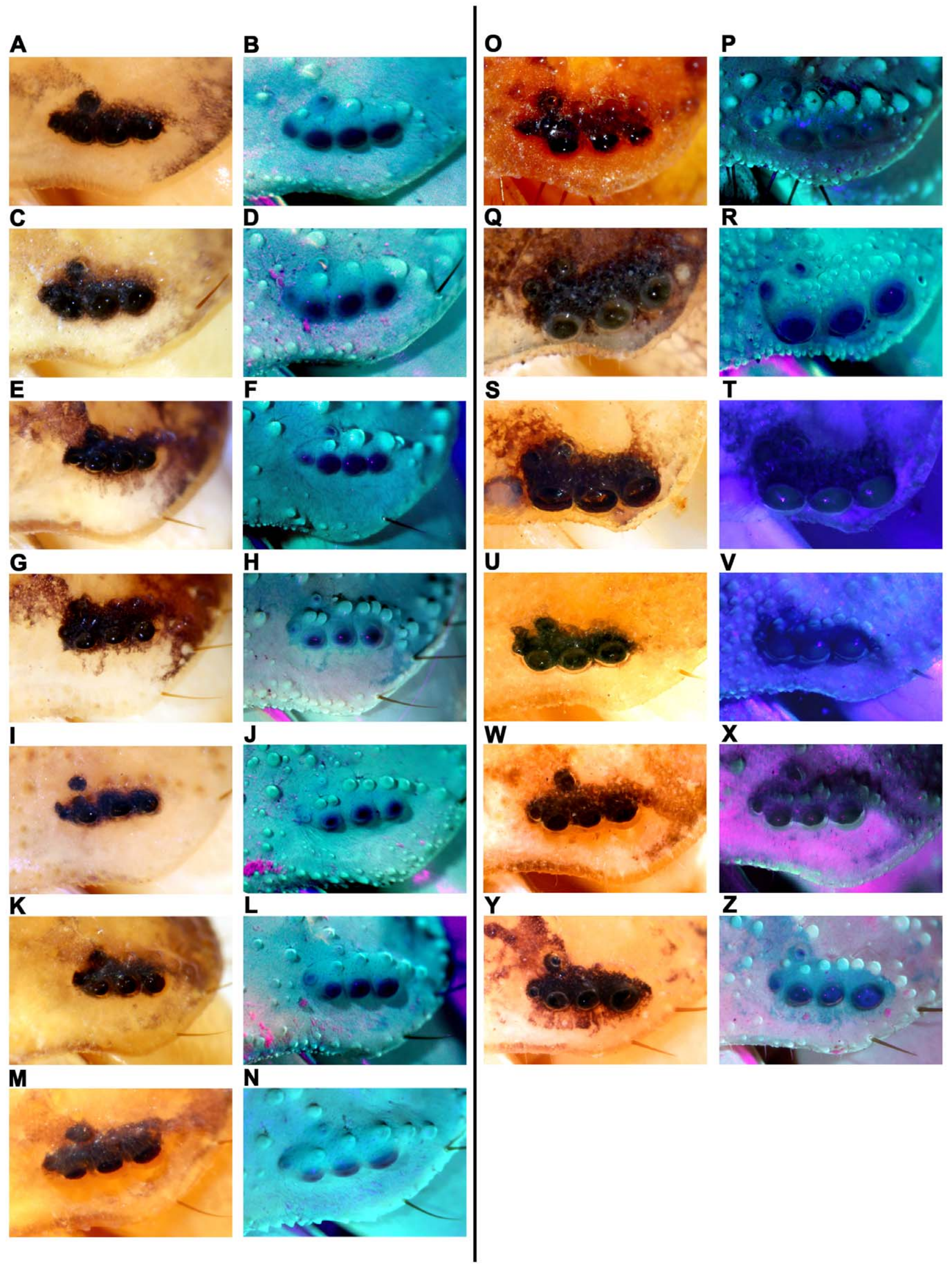


Figure 3. Lateral eye area of representive species and subspecies. (A)\&(B) M. eupeus thersites, (C)\&(D) M. eupeus mongolcus, (E)\&(F) M. caucasicus przewalskii, $(\mathrm{G}) \&(\mathrm{H})$ M. caucasicus intermedius, $(\mathrm{I}) \&(\mathrm{~J})$ M. bolensis, $(\mathrm{K}) \&(\mathrm{~L})$ M. longichelus, $(\mathrm{M}) \&(\mathrm{~N})$ M. karshius. $(\mathrm{O}) \&(\mathrm{P}) H$. songi, $(\mathrm{Q}) \&{ }^{\circledR} \mathrm{L}$. mucronatus, (S)\&(T) I. (Reddyanus) assamensis, $(\mathrm{U}) \&(\mathrm{~V})$ R. xinjianganus, $(\mathrm{W}) \&(\mathrm{X})$ S. gracilis, $(\mathrm{Y}) \&(\mathrm{Z})$ B. draa. doi:10.1371/journal.pone.0055125.g003

"overlooking" of the No. 4 and 5 lateral eyes should be a common gap.

Schliwa \& Fleissner [7] measured lateral eyes of Androctonus australis and reported "approximately $0.3 \mathrm{~mm}$ " for No. $1-3$ and "ranging from 0.1-0.2 mm" for No. 4 \& 5. Kishida [9] made a good re-description for $M$. martensii with five lateral eyes. What need to be highlighted here is Tikader and Bastawade's work [20].
In their book "Fauna of India, Scorpions", all Buthidae species and subspecies (43 Species and subspecies) except those in the genus Charmus were precisely depicted and illustrated with five pairs of lateral eyes. Besides, Finnegan (1932), Fleissner (1974), Schliwa \& Fleissner (1980), Qi \& Lourenço (2007), Lowe (2010), Javed, et al. (2010) provided useful depictions, figures or photos in their publications, other taxonomists involved in the Table 2
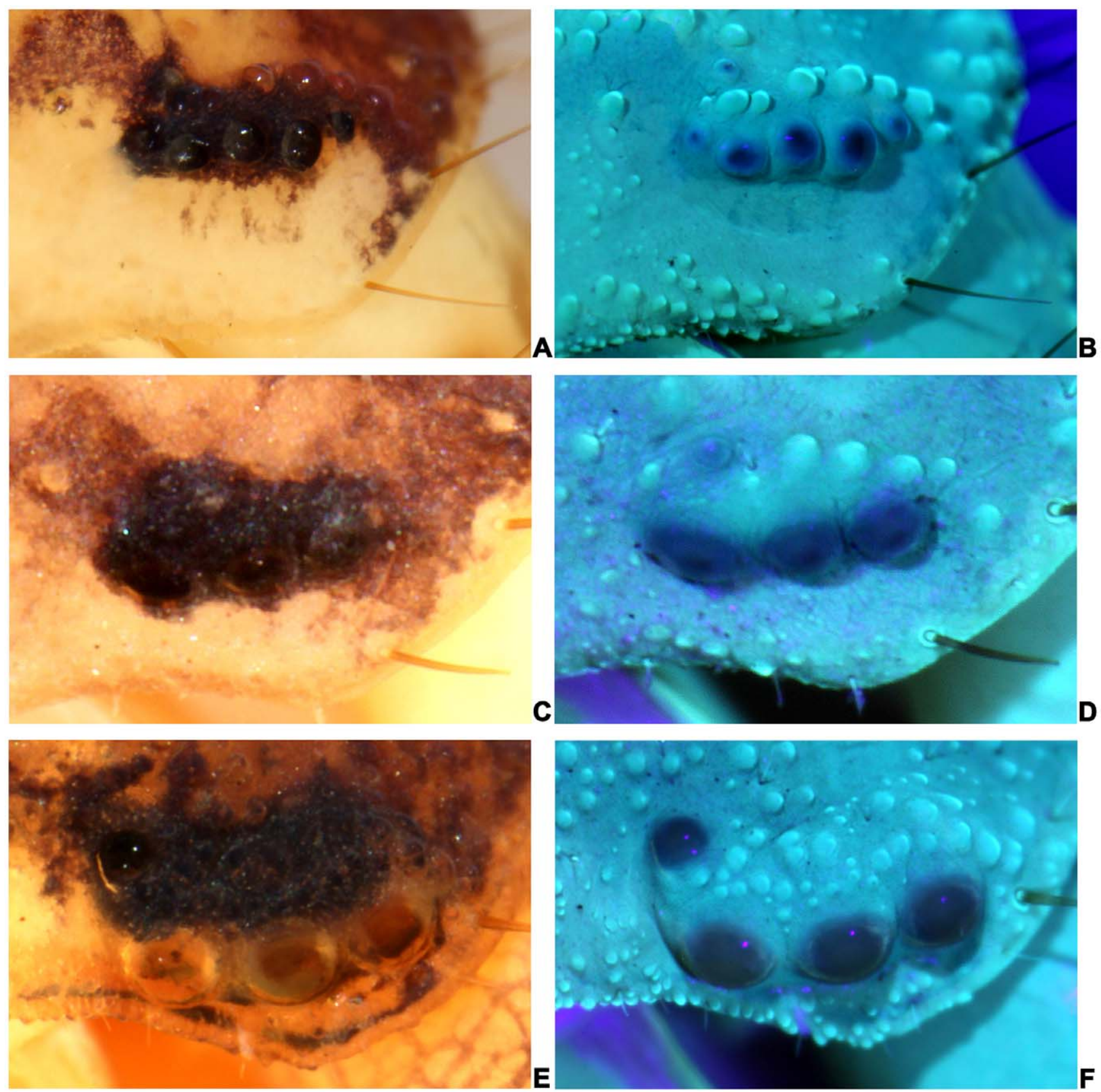

Figure 4. Representive specimens with exceptional number of lateral eyes. (A)\&(B) A specimen with 6 lateral eyes, M. caucasicus intermedius, (C)\&(D) A specimen lacking No. 4 lateral eye, M. martensii martensii, (E)\&(F) A specimen lacking No. 5 lateral eye, L. mucronatus. doi:10.1371/journal.pone.0055125.9004 
Table 2. Species and Publications with Descriptions of Five Pairs of Lateral Eyes.

\begin{tabular}{|c|c|c|c|c|c|}
\hline Species & Location(s) & Reference(s) & Species & Location(s) & Reference(s) \\
\hline Apistobuthus susanae & Asia: Iran & {$[27]$} & $\begin{array}{l}\text { Isometrus } \\
\text { (Reddyanus) } \\
\text { isadensis }\end{array}$ & Asia: India & $\begin{array}{l}\text { [20] (originally depicted as Isometrus } \\
\text { (Raddyanus) isadensis) }\end{array}$ \\
\hline Apistobuthus pterygocercus & $\begin{array}{l}\text { Asia: Arabia, } \\
\text { Oman }\end{array}$ & {$[27,28]$} & $\begin{array}{l}\text { Isometrus } \\
\text { (Reddyanus) } \\
\text { acanthurus }\end{array}$ & Asia: India & $\begin{array}{l}\text { [20] (originally depicted as Isometrus } \\
\text { (Raddyanus) acanthurus) }\end{array}$ \\
\hline Androctonus funestus & $\begin{array}{l}\text { Africa: North } \\
\text { Africa }\end{array}$ & [29] & $\begin{array}{l}\text { Isometrus } \\
\text { (Reddyanus) } \\
\text { corbeti }\end{array}$ & Asia: India & $\begin{array}{l}\text { [20] (originally depicted as Isometrus } \\
\text { (Raddyanus) corbeti) }\end{array}$ \\
\hline Androctonus australis & $\begin{array}{l}\text { Africa: North } \\
\text { Africa }\end{array}$ & {$[7,8,30]$} & Lychas gravelyi & Asia: Burma & {$[20]$} \\
\hline Androctonus finitimus & $\begin{array}{l}\text { Asia: Pakistan, } \\
\text { India }\end{array}$ & $\begin{array}{l}\text { [20](originally depicted as Androctonus } \\
\text { australis finitimu) }\end{array}$ & Lychas nigristernis & Asia: India & {$[20]$} \\
\hline Buthoscorpio rayalensis & Asia: India & {$[31]$} & Lychas biharensis & Asia: India & {$[20]$} \\
\hline Buthoscorpio indicus & Asia: India & [32] & Lychas kamshetensis & Asia: India & {$[20]$} \\
\hline Buthoscorpio sarasinorum & Asia: Sri Lanka & {$[32]$} & Lychas rugosus & Asia: India & $\begin{array}{l}\text { [20] (originally depicted as (Lychas } \\
\text { (Alterotrichus) rugosus) }\end{array}$ \\
\hline Buthacus agarwali & Asia: India & [33] & Lychas hendersoni & Asia: India & $\begin{array}{l}\text { [20] (originally depicted as (Lychas } \\
\text { (Alterotrichus) hendersoni) }\end{array}$ \\
\hline $\begin{array}{l}\text { Buthacus arenicola } \\
\text { maroccanus }\end{array}$ & Africa: Marocco & [34] & Lychas tricarinatus & Asia: India & $\begin{array}{l}\text { [20] (originally depicted as (Lychas } \\
\text { (Endotrichus) tricarinatus) }\end{array}$ \\
\hline $\begin{array}{l}\text { Buthacus leptochelys } \\
\text { algerianus }\end{array}$ & Africa: Algeria & [34] & Lychas laevifrons & Asia: India & $\begin{array}{l}\text { [20] (originally depicted as (Lychas } \\
\text { (Endotrichus) laevifrons) }\end{array}$ \\
\hline Buthacus birulai & Africa: Algeria & [34] & Lychas scaber & Asia: India & $\begin{array}{l}\text { [20] (originally depicted as (Lychas } \\
\text { (Endotrichus) scaber) }\end{array}$ \\
\hline Buthacus mahraouii & Africa: Morocco & [35] & Lychas albimanus & Asia: India & $\begin{array}{l}\text { [20] (originally depicted as (Lychas } \\
\text { (Endotrichus) albimanus) }\end{array}$ \\
\hline Buthiscus politus & Asia: India & $\begin{array}{l}\text { [20] (originally depicted as Stenochirus } \\
\text { Politus) }\end{array}$ & Lychas biharensis & Asia: India & $\begin{array}{l}\text { [20] (originally depicted as (Lychas } \\
\text { (Endotrichus) biharensis) }\end{array}$ \\
\hline Buthiscus sarasinorum & Asia: India & $\begin{array}{l}\text { [20] (originally depicted as Stenochirus } \\
\text { sarasinorum) }\end{array}$ & Lychas kamshetensis & Asia: India & $\begin{array}{l}\text { [20] (originally depicted as (Lychas } \\
\text { (Endotrichus) kamshetensis) }\end{array}$ \\
\hline $\begin{array}{l}\text { Compsobuthus } \\
\text { nematodactylus }\end{array}$ & Asia: Oman & {$[36]$} & Lychas aareyensis & Asia: India & {$[37]$} \\
\hline $\begin{array}{l}\text { Compsobuthus } \\
\text { rugosulus }\end{array}$ & Asia: India & $\begin{array}{l}\text { [20] (originally depicted as } \\
\text { Compsobuthus } \\
\text { acutecarinatus rugosulus) }\end{array}$ & $\begin{array}{l}\text { Mauritanobuthus } \\
\text { geniezi }\end{array}$ & $\begin{array}{l}\text { Africa: } \\
\text { Mauritania }\end{array}$ & [38] \\
\hline Compsobuthus atrostriatus & Asia: India & $\begin{array}{l}\text { [20] (originally depicted as Vachonus } \\
\text { atrostriatus) }\end{array}$ & Orthochirus krishnai & Asia: India & {$[20,39]$} \\
\hline $\begin{array}{l}\text { Hemibuthus } \\
\text { crassimanus }\end{array}$ & Asia: India & {$[20]$} & Orthochirus pallidus & Asia: India & {$[20]$} \\
\hline Hottentotta hottentotta & Not mentioned & $\begin{array}{l}\text { [1] (originally depicted as Tityus } \\
\text { hottentotta) }\end{array}$ & $\begin{array}{l}\text { Orthochirus } \\
\text { flavescens }\end{array}$ & Asia: India & {$[20]$} \\
\hline Hottentotta saxinatans & Asia: Oman & {$[40]$} & Orthochirus bicolor & Asia: India & {$[20]$} \\
\hline Hottentotta pellucidus & Asia: Oman & {$[40]$} & $\begin{array}{l}\text { Orthochirus } \\
\text { bastawadei }\end{array}$ & Asia: India & {$[41]$} \\
\hline Hottentotta penjabensis & Asia: India & $\begin{array}{l}\text { [20] (originally depicted as Buthotus } \\
\text { alticola punjabensis) }\end{array}$ & $\begin{array}{l}\text { Orthochirus } \\
\text { scrobiculosus }\end{array}$ & Asia: India & $\begin{array}{l}\text { [20] (originally depicted as Orthochirus } \\
\text { melanurus) }\end{array}$ \\
\hline Hottentotta flavidulus & Asia: Afghanistan & {$[42]$} & $\begin{array}{l}\text { Odontobuthus } \\
\text { odonturus }\end{array}$ & Asia: India & $\begin{array}{l}\text { [20] (originally depicted as } \\
\text { Odontobuthus doriae odonturus) }\end{array}$ \\
\hline Hottentotta rugiscutis & Asia: India & $\begin{array}{l}\text { [20] (originally depicted as Mesobuthus } \\
\text { rugiscutis) }\end{array}$ & $\begin{array}{l}\text { Parabuthus } \\
\text { transvaalicus }\end{array}$ & Not mentioned & [43] \\
\hline Hottentotta pachyurus & Asia: India & $\begin{array}{l}\text { [20] (originally depicted as Mesobuthus } \\
\text { pachyurus) }\end{array}$ & $\begin{array}{l}\text { Parabuthus } \\
\text { glabrimanus }\end{array}$ & Africa: Namibia & {$[44]$} \\
\hline $\begin{array}{l}\text { Isometrus (Isometrus) } \\
\text { sankeriensis }\end{array}$ & Asia: India & {$[45]$} & Parabuthus calvus & $\begin{array}{l}\text { Africa: South } \\
\text { Africa }\end{array}$ & {$[46]$} \\
\hline $\begin{array}{l}\text { Isometrus (Reddyanus) } \\
\text { brachycentrus }\end{array}$ & Asia: India & {$[45]$} & Parabuthus muelleri & Africa: Namibia & {$[47]$} \\
\hline $\begin{array}{l}\text { Isometrus (Reddyanus) } \\
\text { vittatus }\end{array}$ & Asia: India & $\begin{array}{l}\text { [20] (originally depicted as Isometrus } \\
\text { (Raddyanus) vittatus }\end{array}$ & Pseudolychas pegleri & $\begin{array}{l}\text { Africa: South } \\
\text { Africa }\end{array}$ & {$[48]$} \\
\hline
\end{tabular}


Table 2. Cont.

\begin{tabular}{llllll}
\hline & & & & & \\
\hline Species & Location(s) & Reference(s) & Species & Location(s) & Reference(s) \\
\hline $\begin{array}{l}\text { Isometrus (Reddyanus) } \\
\text { rigidulus }\end{array}$ & Asia: India & $\begin{array}{l}\text { [20] (originally depicted as Isometrus } \\
\text { (Raddyanus) rigidulus) }\end{array}$ & $\begin{array}{l}\text { Vachonus } \\
\text { rajasthanicus }\end{array}$ & Asia: India & {$[20]$} \\
$\begin{array}{l}\text { Isometrus (Reddyanus) } \\
\text { brachycentrus }\end{array}$ & Asia: India & $\begin{array}{l}\text { [20] (originally depicted as Isometrus } \\
\text { (Raddyanus) }\end{array}$ & $\begin{array}{l}\text { Vachonus } \\
\text { rajasthanicus }\end{array}$ & Asia: India & [20] \\
$\begin{array}{l}\text { Isometrus (Isometrus) } \\
\text { thurstoni }\end{array}$ & Asia: India & $\begin{array}{l}\text { [20] (originally depicted as Isometrus } \\
\text { (Raddyanus) thurstoni \& Isometrus } \\
\text { (Closotrichus) sankeriensis) }\end{array}$ & & & \\
\hline & & & & & \\
\hline doi:10.1371/journal.pone.0055125.t002 & & & &
\end{tabular}

"References" provided dozens of reports for the model. These researches greatly support the work reported here and further made it possible to draw a general conclusion.

As a result, we confirm that all the Chinese scorpion species of buthids examined here, whether reported in new (most recent in 2011) or old (latest backdated to 1778) publications, have five pairs of lateral eyes. Together with related descriptions published by Tikader and Bastawade [20], we are convinced that the "Fiveeye" model is appropriate to incorporate in descriptions of the genus Mesobuthus. Combined with more other related data collected in Table1 \& Table 2, this model is likely to be generic character of Hottentotta, Lychas, Isometrus, Buthacus, and Orthochirus. And also, we could further conclude that there would be a possibility too that this model could be a general feature in more other buthid genera with much more species that could be found to have five pairs of lateral eyes.

It should not only be a coincidence that the majority of Buthidae species from India and China falls within the "Five-eye" model. Moreover, with examples from Asia and Africa including those from type genus, we have reasons to believe that a general significance to this model in the Old World buthid genera is possible and further in the whole Buthidae family, as majority of buthid genera distribute in the Old World, mainly Asia and Africa $[52,53]$. Although, it can now be confirmed that the "Five-eye" model is much more common among buthid species and genera than what is known before. In addition, this study has managed to prove a general trend of oversight in recognizing the presence of lateral eyes No. 4 and 5.

We propose four main factors which contributed to this error:

1. Difficulties faced during examining of specimens;

2. Traditional and insufficient examining methods;

3. Lack of development of the lateral eyes in some of the specimens;

4. Insufficient number of samples examined during the study.

\section{References}

1. Koch CL (1837) Übersicht des Arachnidensystems. C. H. Zeh'sche Buchhandlung: Nürnberg.

2. Lankester E (1885) Notes on certain points in the anatomy and generic characteristics of Scorpions. Trans Zool Soc(London) 11: 372-384.

3. Stockwell SA (1989) Revision of the phylogeny and higher classification of scorpions (Chelicerata) [dissertation]: University of California, Berkeley.

4. Kjellesvig-Waering EN (1986) A Restudy of the fossil Scorpionida of the world. Ithaca, N.Y., U.S.A.: Paleontological Research Institution.

5. Soleglad M, Fet V (2003) High-level systematics and phylogeny of the extant scorpions (Scorpiones: Orthosterni). Euscorpius 11: 1-175.

6. Rein JO (2012) The scorpion files. Norwegian University of Science and Technology.

7. Schliwa M, Fleissner G (1980) The lateral eyes of the scorpion, Androctonus australis. Cell and Tissue Research 206: 95-114.

8. Fleissner G (1974) Circadiane Adaptation und Schirmpigmentverlagerung in den Sehzellen der Medianaugen vonAndroctonus australis L.(Buthidae,
As reported in the results, most of the difficulties could be overcome by the use of UV light as well as new examining protocols. Variation in the number of lateral eyes among different specimens of the same species would be common in spite it is very small in proportion (Table 1). Therefore, this error might occur when small samples are used in the studies.

With this general trend of oversight, we believe we are at the tip of major discoveries amidst many arising questions in search of answers: What status of eye numbers are there in the other genera and species in Buthidae? How many genera and species have this "Five-eye" model are there? Are there other models with four pairs of lateral eyes (as in the genus Charmus) or less, where are they and which eye model holds the majority?

Clarifying the use of character 'number of lateral eyes' is important not only in taxonomic studies but also in other research areas, such as evolution and behavior. As there are nearly 1000 species and 90 genera in Buthidae, most of the published species need to be rechecked are suggested to be rechecked here. This would need concerted effort from all concerned in order for us to be able to draw the conclusion and appreciate the contributing importance of this character in the taxonomy of scorpions.

\section{Acknowledgments}

We are most grateful to Prof. Dr. A. Sasekumar, Professor Guodong Ren, Fuming Shi, Feng Zhang for their help in the work. Senior Expert Mingshen Guo kindly assisted in improving the technology of Photomicrography. Thanks are also due to Dr. Lorenzo Prendini for presenting us part of his collections.

\section{Author Contributions}

Conceived and designed the experiments: XFY MSZ. Performed the experiments: XFY. Analyzed the data: XFY YNR WRL MSZ. Contributed reagents/materials/analysis tools: XFY MSZ. Wrote the paper: XFY YNR WRL.

Scorpiones). Journal of Comparative Physiology A: Neuroethology, Sensory, Neural, and Behavioral Physiology 91: 399-416.

9. Kishida K (1939) Arachnida of Jehol. Order Scorpiones. Report of the first Scientific Expedition to Manchoukuo under the leadership of Shigeyasu Tokunaga, June-October 1933: 49-67.

10. Qi JX, Zhu MS, Lourenço W (2004) Redescription of Mesobuthus martensii martensii (Karsch, 1879)(Scorpiones: Buthidae) from China. Revista ibérica de aracnología 10: 137-144.

11. Sun D, Sun ZN (2011) Notes on the genus Mesobuthus (Scorpiones: Buthidae) in China, with description of a new species. Journal of Arachnology 39: 59-75.

12. Birula AA (1911) Arachnologische Beiträge. I. Zur Scorpionen-und SolifugenFauna des Chinesischen Reiches. Revue Russe d'Entomologie 11: 195-199.

13. Birula AA (1917) Chlenistobryukhie paukoobraznye Kavkazskogo Kraya. Part I. Scorpiones. Zapiski Kavkazskogo Muzeya 5: 1-253. 
14. Mirshamsi O, Sari A, Elahi E, Hosseinie S (2011) Mesobuthus eupeus (Scorpiones: Buthidae) from Iran: A polytypic species complex. Zootaxa 2929: $1-21$.

15. Birula AA (1904) Miscellanea scorpiologica. VI.Ueber einige Buthus-Arten Centralasiens nebst ihrer geographischen Verbreitung. Annuaire du Muse e Zoologique de l'Acade mie Impe riale des Sciences de St-Pe tersbourg 9: 20-27.

16. Sun D, Zhu M (2010) A new species of the genus Mesobuthus Vachon, 1950 (Scorpiones, Buthidae) from Xinjiang, China. ZooKeys 37: 1-12.

17. Birula AA (1897) Miscellanea scorpiologica. II. Zur Synonymie der russischen Scorpione. Annuaire du Musée Zoologique de l’Académie Impériale des Sciences de St-Pétersbourg 2: 377-391.

18. Sun D, Zhu MS, Lourenço WR (2010) A new species of Mesobuthus (Scorpiones: Buthidae) from Xinjiang, China, with notes on Mesobuthus songi. Journal of Arachnology 38: 35-43.

19. Lourenco WR, Qi J, Zhu MS (2005) Description of two new species of scorpions from China (Tibet) belonging to the genera Mesobuthus Vachon (Buthidae) and Heterometrus Ehrenberg (Scorpionidae). Zootaxa 985: 1-16.

20. Tikader BK, Bastawade DB (1983) Fauna of India: Scorpions. Scorpionida: Arachnida Vol III.

21. Lourenço WR, Qi JX, Zhu MS (2005) DESCRIPTION OF A NEW SPECIES OF ISOMETRUS EHRENBERG 1828 (SCORPIONES, BUTHIDAE) FROM THE ISLAND OF HAINAN, CHINA Boletín Sociedad Entomológica Aragonesa 1: 57-63.

22. Lourenço WR, Zhu MS (2008) A New Species of the Genus Isometrus Ehrenberg 1828 from China (Scorpiones, Buthidae). Acta Zootaxonomica Sinica 33: 264-271.

23. Di Z, He Y, Wu Y, Cao Z, Liu H, et al. (2011) The scorpions of Yunnan (China): updated identification key, new record and redescriptions of Euscorpiops kubani and E. shidian (Arachnida, Scorpiones). ZooKeys: 1.

24. Lourenço WR, Sun D, Zhu MS (2010) Razianus xinj ianganus sp. nov. :A New Record Genus and New Species of (Scorpiones,Buthidae)from China. Journal of Hebei University (Natural Science Edition) 30: 307-312.

25. Lourenço WR, Sun D, Zhu MS (2009) About the presence of the genus Buthus Leach, 1815 in Mauritania, with description of a new species (Scorpiones, Buthidae). Boletín de la SEA: 71-75.

26. Lourenço WR, Leguin EA (2010) Complements a la morphologie de kraepelinia palpator birula, 1903)(scorpiones, buthidae) al aide d une etude au microscope electronique au balayage. Boletín de la SEA: 307-310.

27. Navidpour S, Lowe G (2009) Revised diagnosis and redescription of Apistobuthus susanae (Scorpiones, Buthidae). Journal of Arachnology 37: 45-59.

28. Finnegan S (1932) Report on the scorpions collected by Mr. Bertram Thomas in Arabia. Journal of the Linnean Society of London, Zoology 38: 91-98.

29. Lankester E, Bourne A (1883) The minute structure of the lateral and the central eyes of Scorpio and Limulus. Quart J Microsc Sci 23: 177.

30. Fleissner G (1977) Scorpion lateral eyes: Extremely sensitive receptors of Zeitgeber stimuli. Journal of Comparative Physiology A: Neuroethology, Sensory, Neural, and Behavioral Physiology 118: 101-108.

31. Javed SMM, Rao KT, Mirza ZA, Sanap RV, Tampal F (2010) A New Species of Scorpion of the Genus Buthoscorpio Werner, 1936 (Scorpiones: Buthidae) from Andhra Pradesh, India. Euscorpius No.98: 1-11.

32. Lourenço WR (2012) Further taxonomic considerations on the genus buthoscorpio Werner, 1936 (Scorpiones, Buthidae), with description of a new species from India. BSEA 50: 187-192.

33. Zambre AM, Lourenço WR (2010) A new species of Buthacus Birula, 1908 (Scorpiones, Buthidae) from India. Boletín de la SEA: 115-119.
34. Lourenço WR (2006) Further considerations on the genus Buthacus Birula, 1908 (Scorpiones, Buthidae), with a description of one new species and two new subspecies. Boletín de la SEA: 59-70.

35. Lourenço WR (2004) New considerations on the Northwestern African species of Buthacus Birula (Scorpiones, Buthidae), and description of a new species. Revista ibérica de aracnología: 225-231.

36. Lowe G (2009) A New Lithophilic Compsobuthus Vachon, 1949 (Scorpiones: Buthidae) from Northern Oman. Euscorpius No.90: 1-13.

37. Mirza Z, Sanap R (2010) Description of a new species of scorpion of the genus Lychas CL Koch, 1845 (Scorpiones: Buthidae) from Maharashtra, India. Journal of Threatened Taxa 2: 789-796.

38. Qi JX, Lourenço WR (2007) Distribution of endemic relict groups of Saharan scorpions, with the description of new genus and species from Mauritania. Comptes Rendus Biologies 330: 80-85.

39. Zambre A, Bastawade D (2009) Description of male Orthochirus krishnai (Scorpiones: Buthidae) from India, with comments on its taxonomic status. Journal of Threatened Taxa 1: 621-623.

40. Lowe G (2010) Two New Species of Hottentotta Birula, 1908 (Scorpiones: Buthidae) from Northern Oman Euscorpius No.103: 1-23.

41. Zambre AM, Mirza ZA, Rajesh VS, Upadhye R, Javed SMM (2011) A new species of scorpion of the genus Orthochirus Karsch, 1892 (Scorpiones: Buthidae) from Maharashtra, India. Euscorpius 107: 1-12.

42. Teruel R, Rein JO (2010) A new Hottentotta Birula, 1908 from Afghanistan, with a note on the generic position of Mesobuthus songi Lourenço, Oi et Zhu, 2005 (Scorpiones: Buthidae) NO. 94: 1-8.

43. Spreitzer A, Melzer RR (2003) The nymphal eyes of Parabuthus transvaalicus Purcell, 1899 (Buthidae): an accessory lateral eye in a scorpion. Zoologischer Anzeiger-A Journal of Comparative Zoology 242: 137-143.

44. Prendini L, Esposito LA (2010) A reanalysis of Parabuthus (Scorpiones: Buthidae) phylogeny with descriptions of two new Parabuthus species endemic to the Central Namib gravel plains, Namibia. Zoological Journal of the Linnean Society 159: 673-710.

45. Sureshan P, Bastawade D, Radhakrishnan C (2007) Taxonomic studies on a collection of scorpions (Scorpiones: Archnida) from Western Ghats In Kerala, India with two New distribution records. Zoos print journal 22: 2903-2908.

46. Prendini L (2004) The systematics of southern African Parabuthus Pocock (Scorpiones, Buthidae): revisions to the taxonomy and key to the species. Journal of Arachnology 32: 109-187.

47. Prendini L (2003) Discovery of the male of Parabuthus muelleri, and implications for the phylogeny of Parabuthus (Scorpiones: Buthidae). American Museum Novitates: 1-24.

48. Prendini L (2004) Systematics of the genus Pseudolychas Kraepelin (Scorpiones: Buthidae). Annals of the Entomological Society of America 97: 37-63.

49. Polis GA (1990) The Biology of scorpions. Stanford, Calif:: Stanford University Press. xxiii, 587 p. p.

50. Kovař́k F (2004) Revision and taxonomic position of genera Afghanorthochirus Lourenço \& Vachon, Baloorthochirus Kovař́k, Butheolus Simon, Nanobuthus Pocock, Orthochiroides Kovařík, Pakistanorthochirus Lourenço, and Asian Orthochirus Karsch, with descriptions of twelve new species (Scorpiones, Buthidae). Euscorpius 16: 1-33.

51. Vachon M (1958) Scorpionidea (Chelicerata) de l'Afghanistan. The 3rd Danish Expedition to Central Asia(Zoological Results 23) Videnskabelige meddelelser fra Dansk naturhistorisk forening i Købehavn 120: 121-187.

52. Fet V, Sissom WD, Lowe G, Braunwalder ME (2000) Catalog of the scorpions of the world (1758-1998): New York Entomological Society.

53. Fet V, Gantenbein B, Gromov A, Lowe G, Lourenço W (2003) The first molecular phylogeny of Buthidae (Scorpiones). Euscorpius 4: 1-10. 